\title{
Commentary on: "Does caffeine enhance bowel recovery after elective colorectal resection? A prospective double-blinded randomized clinical trial" Tech Coloproctol. 2021 Apr 26. doi: 10.1007/ s10151-021-02450-7
}

\section{P. K. Korolkiewicz ${ }^{1}$ iD}

Received: 1 June 2021 / Accepted: 12 June 2021 / Published online: 25 June 2021

(c) The Author(s) 2021

\section{Dear Sir,}

It is with great interest that I read the results of the study performed by Parnasa et al. [1], which evaluated the safety and efficacy of orally administered caffeine citrate in patients undergoing abdominal surgery.

While the paper confirmed the beneficial effect of caffeine on postoperative gastrointestinal motility, I would like to hypothesize that the results could have been optimized by a simple modification of the drug administration schedule. It is well-known fact that any pharmacological compound exerts its most potent pharmacologic effect after achieving a steady-state concentration. The $50 \%$ of the steady-state concentration is reached after one half-life $\left(t_{1 / 2}\right), 75 \%$ after two $t_{1 / 2}$, and over $90 \%$ after four $t_{1 / 2}$ [2]. The mean serum caffeine half-life for the orally ingested caffeine solution in healthy subjects equals $5.7 \mathrm{~h} \mathrm{[3].} \mathrm{Therefore,} \mathrm{most} \mathrm{of} \mathrm{the}$ patients in the study will have reached the steady state approximately $23 \mathrm{~h}$ after dosing initiation. Thus, the relatively modest effects observed by the authors could have been more pronounced if the caffeine "loading" was initiated prior to hospital admission and continued as described in the study protocol. This hypothesis might be worth taking into account, while further exploring the effects of caffeine in enhanced recovery after surgery protocols.

Additionally, based on the information in the paper, it is not clear whether both treatment arms were balanced with respect to the administration of nonsteroidal anti-inflammatory drugs (NSAIDs) as a part of postoperative analgesia. This confounding factor is especially important in the light

P. K. Korolkiewicz

pawelkorolkiewicz@gumed.edu.pl

1 Medical University of Gdansk, M. Skłodowskiej-Curie 3a, 80-210 Gdańsk, Poland of the ketorolac effect on the enhancement of normal bowel function recovery after surgical intervention. Stratification according to whether the patients have or not have taken NSAIDs as analgesics could have potentially taken care of the variable.

Author contribution Not applicable.

Funding Not applicable.

Availability of data and materials Not applicable.

Code availability Not applicable.

\section{Declarations}

Conflict of interest The author declares that he has no conflict of interest.

Ethics approval Not applicable.

Human and animal rights Not applicable.

Consent to participate Not applicable.

Consent for publication Not applicable.

Open Access This article is licensed under a Creative Commons Attribution 4.0 International License, which permits use, sharing, adaptation, distribution and reproduction in any medium or format, as long as you give appropriate credit to the original author(s) and the source, provide a link to the Creative Commons licence, and indicate if changes were made. The images or other third party material in this article are included in the article's Creative Commons licence, unless indicated otherwise in a credit line to the material. If material is not included in the article's Creative Commons licence and your intended use is not permitted by statutory regulation or exceeds the permitted use, you will 
need to obtain permission directly from the copyright holder. To view a copy of this licence, visit http://creativecommons.org/licenses/by/4.0/.

\section{References}

1. Parnasa SY, Marom G, Bdolah-Abram T, Gefen R, Luques L, Michael S, Mizrahi I, Abu-Gazala M, Rivkind AI, Mintz Y, Pikarsky AJ, Shussman N (2021) Does caffeine enhance bowel recovery after elective colorectal resection? A prospective doubleblinded randomized clinical trial. Tech Coloproctol. https://doi. org/10.1007/s10151-021-02450-7
2. Holford NHG (2018) Pharmacokinetics \& pharmacodynamics: rational dosing \& the time course of drug action. In: Katzung BG (ed) Basic and clinical pharmacology, 14th edn. McGraw Hill Education, New York, USA, pp 41-55

3. Statland BE, Demas TJ (1980) Serum caffeine half-lives. Healthy subjects vs. patients having alcoholic hepatic disease. Am J Clin Pathol 73:390-393

Publisher's Note Springer Nature remains neutral with regard to jurisdictional claims in published maps and institutional affiliations. 